\title{
Evolutions in Photojournalism in India (2001 to 2011)
}

\section{Pradeep Tewari, Kurukshetra University, India}

\begin{abstract}
This study investigated the revolutionary impact of digitization on the photojournalism in India during the 2001 and 2011. The digital camera becomes very popular, almost every person is having a digital camera or cell phone with camera features. Most (82.2\%) of the photojournalist strongly agree that the use of digital camera has increased, 65.3\% says quality of image increased. $30.7 \%$ photojournalist strongly agreed, with the development of new technology newspapers are reducing their photo staff. $74.3 \%$ photojournalist strongly agreed the work load of photojournalist has increased . 57.4\% photojournalist believed that level of education increased among photojournalist in India.
\end{abstract}

Keywords: Photojournalist, digital camera, newspaper photography, photojournalism, mobile camera. 


\section{Introduction}

Visuals in the newspapers are the one item that the readers react to immediately than the words and they retain it. A renowned psychologist Albert Mehrabian (1981) has demonstrated through experiments that $93 \%$ of communication is nonverbal. Photography is a very powerful medium of visual communication. We see the world with the help of our eyes that's why visuals or images are important for every newspaper.

Photojournalism is taking photographs which tell a story. It is frequently used to explain still images but it can also apply to news broadcasts. Photojournalism is distinguished from others forms of journalism due to its qualities. The images must be timely, referring to the fact they have meaning in context to recent event, they are objective, meaning the situation implied by the image is a fair representation of the events in both content and time, and they are narrative, which is when the images combine with other news elements to make the facts relatable to the viewer and/or reader on a cultural level.

Photojournalism is a specialisation within photography; it is used in the media industry to take news worthy photos of events. The important task of a photojournalist is to click images to go along news items (both broadcast and print media like TV shows and newspapers/magazine). A good news photo often explains the whole story before listening or reading the text. Photographs by photojournalist capture the viewer's attention and motivate and lure the readers to continue listening to or reading the story.

Photojournalists always hunt for action pictures with expressions and uniqueness. Readers always like to feel something was going on when photo was taken. The image with good expression is always preferred in the newspaper industry. Photojournalist always captures expression to tell the news in an effective manner. People like to have a glimpse of the action that cannot be revisited in reality. Photojournalist takes the photographs of the unique moments of people's lives to tell the story.

Photojournalists must make decisions instantly as well as carry their own equipment, all while being exposed to different obstacles such as physical danger, weather, enormous crowds, and much more. With the speeding increase in the evolution of Science, Technology 
and gadgets have made its entrance almost at every point of life whether it is medical science, vehicles, gadgets and even in the fourth pillar of democracy which we term as "Media”. Photos plays an important role in each newspapers. The routin process of a photosection has developed with the growth of digital technology in last 10 years in India. New technologies have the potential to deliver news photos within the newsroom whithout wasting the time. Digital technology is playing a significant role for making editorial-decision very quick. As know a photojournalist can send his or her assignments without delay to the newsroom, and editors can take their decision from outside the offices after check the photographs on their mobiles or laptops.

With the evolution of new gadgets and advacement in technology, the working in Media has become quick and responsive. Gadgets such as high performance DSLR cameras or highly equipped mobile phones have not only made the working of the Media persons better but also faster. Nowdays the media is dependent on visuals which are of great impact in the newspapers and even in the Electronic media. Without visuals a story or a news can be said as if only heard but not seen.

In spite of technical development in the field of photojournalism, the core of the profession has remained the same: to capture the events truthfully as you can. Mark Lent (2010) reported that photojournalism is more than megapixels and binary ones and zeros with digital signaling. It's a process of thought and emotion from people who are not only trained in all of those technical aspects, but are caring and involved documentarians who identify and capture the essence of their subject in many different types of media with many different situations on a daily basis.

The purpose of this study was to exmine the evolutions in Photojournalism in last decade (2001-2011) in India. This study will also focus on how photojournalists' affects with the development digital technology in recent years.

\section{Literature Review}

Initialy photos and films were scaned and converted into digital format and stored in CD/Floppy. It was the first phase of digitization of photojournalism took place in 1980s. After the invention of digital camera (1975) by Kodak engineer Steve Sasson and his team. 
Second phase began a decade later, with the adoption of digital cameras (Cookman, 2009; Newton, 2009a). Digitization transformed the working style of photojournalist around the world (Bock, 2008; Bossen et al., 2006;Cookman, 2009; Fahmy and Smith, 2003; Longton, 2009; Russial, 2000).

After the introduction of digital technology in print media, photojournalists faced several challenges, as they were not trained and expert to the new technology (Greenwood and Reinardy,2011; Russial and Wanta, 1998), however they have to take photos and send them immediately to the newsroom, as well as managing archives and digitally editing their own photos (Bock, 2008; Bossen et al., 2006; Cookman, 2009;Fahmy and Smith, 2003; Newton, 2009a; Yaschur, 2012b). Now, photojournalists have to face many challenges, such as the massive pressures of time, workload, job insecurity, and the pressing need to redefine their professional identity (Bock, 2008, 2011; Buehner, 2013; Greenwood and Reinardy, 2011; Mortensen and Keshelashvili, 2013).

An ordinary citizen, first on the scene with a camera or mobile camera and take the photographs of the particular event and give theses photos to media orgnisation for the publication called citizen photojournalist. While photojournalists regularly take photographs of the common place, in difficult situations, and where photography is not a social norm, amateurs typically shoot unusual events and only when it is considered culturally acceptable (Harrison, 2004). The tendency for amateurs to photograph major events is not new (Cookman, 2009), but the popularization of digital photography and ubiquity of camera phones has further facilitated this practice. Although the pressures on photojournalist have risen in the recent years. Since its inception and institutionalization in the mid- $20^{\text {th }}$ century (Brennen, 1998; Zelizer, 1995), for recognition and existence of photojournalism, photojournalist had to struggle (Brennen, 1998; Zelizer, 1995).

Previous studies suggested that digitization is not harming the profession of photojournalism,since it might help take the edge off the time pressures of chemical photography (Fahmy and Smith, 2003), The present study wishes to enhance the range of existing research, using a 10-year perspective after digitization was adopted by Indian newspapers photojournalist.This study will also try to explore the current threats facing photojournalist of India. The education level of photojournalist is changing very rapidly, now 
most of the media orgnisation hiring highly educated photojournalist. The abilities of the working photojournalist have changed almost as much as the technology in the past 20 years. Educational requirements of photojournalist have changed as well. Now, media companies require a minimum of a college degree and many prefer a graduate degree as well. Now a photojournalist must be good in IT, writer, videographer, video and photo editor, and computer repair (Mark Lent, 2010). According to Bethune (1984), the educational level of relatively young photographers was much higher than older photographers.

\section{Methodology}

A survey of full-time photojournalists of North India with a minimum circulation of 10,000 was conducted. The list of photojournalist was compiled by cross-referencing the 2012 Press Information Bureau list and Public relation department of different states. Corresponding email addresses of photojournalist were compiled from the various public relation department directories. An invitation to participate in the survey was emailed to 300 photojournalists in March 2012, followed by two email reminders and personal calls on the mobile phone. The survey was completed by 101 respondents (33.6\%), majority were working with influential publications like The Times of India, Hindustan Times, The Indian Express, Daink Bhaskar, and The Tribune. The majority of the sample worked for English newspapers (56.4\%), and the remaining worked for vernacular papers (43.6\%). The sample was selected from North India and not from the other part of the country but even then it represents the trend of the whole country. The sample of the study represents the photojournalist of the entire country.

The questionnaire was to measure photojournalist's views on various aspects. Five categories of response (for example: 1. Strongly Agree 2. Agree 3. Neutral 4. Disagree 5. Strongly disagree) used in this study.

The purpose of the study was to find out the evolutions in the photojournalism in one decade in India. I have used frequency distribution test to check the occurrence of different categories of variables. The questionnaire sent to photojournalists through the e-mail. But the photojournalist of Chandigarh has filled the questionnaire manually as the researcher is stationed in Chandigarh. 


\section{Objectives of the Study}

The objectives of the study are as follows:

1. To find out the change in photojournalism in one decade (2001-2011).

2. To examine the current working condition of Indian photojournalist.

\section{Research Questions}

The following research questions will be answered:

RQ: Have the use of Digital camera increased in the 10 years by the photojournalists?

RQ: Has the quality of images increased drastically?

RQ: Has the sharing of photographs with newsroom become faster?

RQ: Are mobile cameras also contributing to the newspapers?

RQ: Has the contribution of Photographs by the Reporting staff increased?

RQ: Are a common persons / citizen journalist also contributing digital photographs?

RQ: Are the photojournalist staff reduced by the newspapers?

RQ: Do you think workload increased in last 10 years?

RQ: Is salary structure of photojournalist stagnant?

RQ: Have the education level increased among the photojournalist?

A survey was conducted among photojournalists from North India about evolutions in Photojournalism in one decade ( 2001-2011). A sample size of 101 respondents was selected, they were randomly selected by the researcher. The stastistics and the results achived during the survey are as follows.

Table 1: Respondents opinion wheather use of Digital camera increased or not.

\begin{tabular}{|l|c|c|}
\hline & Frequency & Percent \\
\hline Strongly Agree & 83 & 82.2 \\
\hline Agree & 18 & 17.8 \\
\hline Total & 101 & 100.0 \\
\hline
\end{tabular}

Table 1 show the data of photojournalists, who believe that, the use of digital camera has increased in the 10 years by the photojournalist. 82.2\% $(n=83)$ photojournalist strongly agree that the use of digital camera by every professional Photojournalist is increased in last 10 
years.17.8\% $(n=18)$ photojournalist agreed that the use of digital camera increased in the last 10 years.

Table 2: Respondent agree that quality of images increased drastically.

\begin{tabular}{|l|c|c|}
\hline & Frequency & Percent \\
\hline Strongly Agree & 66 & 65.3 \\
\hline Agree & 25 & 24.8 \\
\hline Neutral & 7 & 6.9 \\
\hline Disagree & 3 & 3.0 \\
\hline Total & 101 & 100.0 \\
\hline
\end{tabular}

Table 2 show the data of photojournalists regarding quality of images increased in one decade (2001-2011). The majority of those sampled, that is, 65.30\% $(n=66)$ photojournalist strongly agree that the quality of images increased drastically. $24.80 \%(n=25)$ agreed, $6.90 \%(n=7)$ neutral, and 3\% $(n=3)$ photojournalist are strongly disagree.

Table 3: Respondents agree that sharing of photographs become faster.

\begin{tabular}{|l|c|c|}
\hline & Frequency & Percent \\
\hline Strongly Agree & 73 & 72.3 \\
\hline Agree & 25 & 24.8 \\
\hline Neutral & 2 & 2.0 \\
\hline Disagree & 1 & 1.0 \\
\hline Total & 101 & 100.0 \\
\hline
\end{tabular}

Table 3 provides the data of photojournalists response to sharing of photographs with newsroom become faster. Per the statistics $72.30 \%(n=73)$ are strongly agree and $24.8 \%$ ( $n=25)$ agree, while $2 \%(n=2)$ photojournalist are neutral and $1 \%(n=1)$ are disagree.

Table 4: Respondents agree that mobile cameras also contributing to the newspapers.

\begin{tabular}{|l|c|c|}
\hline & Frequency & Percent \\
\hline Strongly Agree & 25 & 24.8 \\
\hline Agree & 45 & 44.6 \\
\hline
\end{tabular}




\begin{tabular}{|l|c|c|}
\hline Neutral & 27 & 26.7 \\
\hline Disagree & 4 & 4.0 \\
\hline Total & 101 & 100.0 \\
\hline
\end{tabular}

Table 4 show the mobile cameras also contributing to the newspapers.24.8\% $(n=25)$ covered by the study strongly agree mobile cameras ase also contributing in newspapers, $44.6 \%$ $(n=45)$ agree while $26.7 \%(n=27)$ are neutral only $4 \%(n=4)$ disagree.

Table 5: respondent agree that reporting staff increased the photo contribution.

\begin{tabular}{|l|c|c|}
\hline & Frequency & Percent \\
\hline Strongly Agree & 16 & 15.8 \\
\hline Agree & 43 & 42.6 \\
\hline Neutral & 35 & 34.7 \\
\hline Disagree & 6 & 5.9 \\
\hline Strongly disagree & 1 & 1.0 \\
\hline Total & 101 & 100.0 \\
\hline
\end{tabular}

Table 5 shows that photo contribution by the reporters increased in the last 10 years in India. Per the table $15.8 \%(n=16)$ are strongly agree and $42.6 \%(n=43)$ respondent are agree, $34.7 \%$ $(n=35)$ are neutral while only 5.9\% $(n=6)$ disagree and 1\% $(n=1)$ strongly disagree.

Table 6: Respondents that agreed common persons are contributing.

\begin{tabular}{|l|c|c|}
\hline & Frequency & Percent \\
\hline Strongly Agree & 15 & 14.9 \\
\hline Agree & 48 & 47.5 \\
\hline Neutral & 36 & 35.6 \\
\hline Disagree & 2 & 2.0 \\
\hline Total & 101 & 100.0 \\
\hline
\end{tabular}

As per the table 6 common person are also contributing photographs with newspapers. $14.9 \%$ $(n=15)$ respondent are strongly agree, 47.5\% $(n=48)$ are agree and 35.6\% $(n=36)$ are neurtal, wheareas only $2 \%(n=2)$ are disagree. 
Table 7: Respondent that believed photojournalist staff reduced by the newspapers.

\begin{tabular}{|l|c|c|}
\hline & Frequency & Percent \\
\hline Strongly Agree & 31 & 30.7 \\
\hline Agree & 31 & 30.7 \\
\hline Neutral & 31 & 30.7 \\
\hline Disagree & 7 & 6.9 \\
\hline Strongly disagree & 1 & 1.0 \\
\hline Total & 101 & 100.0 \\
\hline
\end{tabular}

According to the table 7, 30.7\% ( $n=31)$ of respondents strongly agreed that photojournalist staff reduced by the newspapers, 30.7\% $(n=31)$ agree and $30.7 \%(n=31)$ are neutral while $6.9 \%(n=7)$ are disagree and only $1 \%(n=1)$ are strongly disagree.

Table 8: Respondent who strongly thinks workload increased in last 10 years.

\begin{tabular}{|l|c|c|}
\hline & Frequency & Percent \\
\hline Strongly Agree & 75 & 74.3 \\
\hline Agree & 19 & 18.8 \\
\hline Neutral & 7 & 6.9 \\
\hline Total & 101 & 100.0 \\
\hline
\end{tabular}

Table 8 shows the workload on the photojournalist increased in last 10 years. $74.3 \%(n=75)$ respondent strongly agree that the workload on the photojournalist has increased, $18.8 \%$ $(n=19)$ agree and 6.9\% $(n=7)$ respondent are neutral.

Table 9: Respondent that agreed that salary structure of photojournalist stagnant.

\begin{tabular}{|l|c|c|}
\hline & Frequency & Percent \\
\hline Strongly Agree & 51 & 50.5 \\
\hline Agree & 34 & 33.7 \\
\hline Neutral & 13 & 12.9 \\
\hline Disagree & 1 & 1.0 \\
\hline Strongly disagree & 2 & 2.0 \\
\hline Total & 101 & 100.0 \\
\hline
\end{tabular}


As per the table 9 majority respondent believe that salary structure of photojournalist is stagnant. $50.5 \%(n=51)$ respondent are strongly agree to that the 'Salary structure is stagnant', 33.7\% ( $n=34)$ agree and 12.9\% $(n=13)$ neutral, whereas $2 \%(n=2)$ photojournalist are strongly disagree and $1 \%(n=1)$ disagree.

Table 10: Respondent who agree that education level increased among the photojournalist.

\begin{tabular}{|l|c|c|}
\hline & Frequency & Percent \\
\hline Strongly Agree & 58 & 57.4 \\
\hline Agree & 37 & 36.6 \\
\hline Neutral & 5 & 5.0 \\
\hline Strongly disagree & 1 & 1.0 \\
\hline Total & 101 & 100.0 \\
\hline
\end{tabular}

Table 10 provides statistical information of the eductaion level among photojournalists have increased in last 10 years in India. $57.4 \%(n=58)$ respondent strongly agree, $36.6 \%(n=37)$ agree , $5 \%(n=5)$ are neutral and only $1 \%(n=1)$ strongly disagree that the education level has incresaed among photojournalist in India.

\section{Discussion}

The findings from this study explain the change in photojournalism in India and reveal how the job of photojournalists' has been changed. Digital technology gave the speed and efficiency to photojournalism as news photos can be taken, transmitted, selected, manipulated, stored, and retrieved instantly. Per the study all the photojournalist in India are using digital camera.

After the addition of computer technology into newspaper production over the last 10 years, many changes have been noticed in the photo departments of the newspapers. Instant sharing of the photos with the newsroom is a major change, now a photojournalist is not dependent to photo lab department. The quality of newspaper photographs increased with the advance digital camera and latest production techniques. Majority (65.3\%) respondent of this study strongly agreed that the quality of photographs has increased in last 10 years and $72.3 \%$ 
photojournalists strongly agree that sharing of photos with the newsroom drastically increased.

With the development of digital technology and easy availability of cameras, a common person is also taking photographs and contributing with the newspapers. With higher resolution mobile camera it become very easy to capture an interesting moments and sending to the newspaper with the help of e-mail. Reporters are also increased contribution of news photographs in newspapers. Most of the media industry is facing financial problems all over the world, most of the respondent of this study agreed that the pay structure of photojournalist is stagnant in India. The workload of photojournalist has increased in last ten years as the photo staff is decreasing over the past ten years. In this study most of the respondent agreed that newspaper have reduced photo staff in last 10 years. Digitization did not create the threats to photojournalism. In some cases most, or even all, staff photographers were laid-off (Bock, 2008; Buehner, 2013; Memmott, 2013). But, the ways in which digital technology was implemented evoked a negative synergy of old and new weaknesses of photojournalists as visual creatures in predominantly textual kingdoms (Lowrey, 2002; Reich and KleinAvraham, 2014).

After the digitization photojournalists have face many responsibility like editing the photos, archiving, tagging, caption writing and making photo gallery for the online edition. Now some of the newspaper management have also introduced the uploading of vedio clipings of daily events. In the preseant study $74.3 \%$ photojournalist strongly agreed that the worklaod has increased in last 10 years. Education level of photojournalists has increased in last 10 years, 57.4\% respondents are strongly agreed. Now all the newspapers management preferring multi tasking photojournalist with good academic background, who can take the photos, video, and write a good caption and edit the photographs. Whereas this study discovered the changes in photojournalism, it could be improved upon. Changes may have begun more than ten years ago, so it is suggested that prospect researchers extend the time frame.

\section{Limitations}

While the findings of this study are unique, the study was not without its limitations. The findings are representat only to India and cannot be generalized to other countries. Next, this 
survey was not open ended and therefore the researchers did not uncover some more issues. Future researchers are encouraged to continue examining photojournalists of multiple countries.

\section{Conclusions}

The main goal of this research was to examine the evolutions in photojournalism in one decade in India. Per the survey of photojournalist the use of digital camera in photojournalism is dominating all the media persons are using digital technology. Survey revealed that $82 \%$ photojournalists strongly agreed and 18\% agree with the increased use of Digital camera during the last 10 years. Workload on the photojournalist has drastically increased in last ten years. The quality of photographs has increased with the help of digital camera. As per the survey $65.3 \%$ strongly agreed, $24.8 \%$ agreed, $6.9 \%$ neutral, and 3\% photojournalists strongly disagreed. The use of mobile camera in the news photography has increased in 2011. Per the survey, 24.8\% strongly agreed, $44.6 \%$ agreed, $27.7 \%$ are neutral, and $4 \%$ strongly disagreed.

Sharing photographs with the newsroom has become faster as compared to the previous method. Use of mobile camera also increased in the news paper photography. Contribution from the citizen journalists, and even the reporters clicking the pictures with their high tech mobiles, the newspaper organizations have also reduced the number of professional photojournalists. Education level has increased in one decade (2001-2011) among the photojournalists, per the survey conducted within the photojournalists of India to know the education level. The study revealed that $58.4 \%$ photojournalist strongly agreed, and $36 \%$ agree that the education level has increased. 


\section{Reference}

Anderson, M. (2013). At newspapers, photographers feel the brunt of job cuts. Retrieved from http://www.pewresearch.org/fact-tank/2013/11/11/at-newspapers-photographersfeel-the-brunt-of-job-cuts/

Bethune, B. (1984). A sociological profile of the daily newspaper photographer. Journalism \& Mass Communication Quarterly, 606-743.

Bock, M.A. (2008). Together in the scrum: practicing news photography for television, print, and broadband. Visual Communication Quarterly 15(3): 169-179.

Brennen, B. (1998). Strategic competition and the value of photographers' work: photojournalism in Gannett newspapers, 1937-1947. American Journalism, 15(2): $59-77$.

Buehner, T.M. (2013). Photojournalism in a changing online environment: a co-orientational study. In: The 63rd annual ICA conference, London, 17-23 June.

Cookman, C. (2009). American photojournalism: Motivations and meanings. Evanston, IL: Northwestern University Press.

Coomes, P. (2013). The business of photojournalism. Retrieved from http://www.bbc.com/news/in-pictures-21418442

Fahmy, S., \& Smith, Z. (2003). Photographers note digital’s advantages, disadvantages. Newspaper Research Journal, I(2): 82-96.

Greenwood, K., \& Reinardy, S. (2011). Self-trained and self motivated: newspaper Photojournalists strive for quality during technological challenges. Visual Communication Quarterly, 18(3):155-166.

Harrison, B. (2004). Snap happy: Toward a sociology of “everyday photography.” In C. J. Pole (Ed.), Studies in Qualitative Methodology: Vol. 7. Seeing is believing? Approaches to visual research (pp.23-39). Oxford, UK: Elsevier.

Langton, L. (2009). Photojournalism and today’s news. Oxford: Wiley-Blackwell Lee, S.M. (2014). The sociology of photojournalism: The adoption of video newspaper staff photographers. Unpublished Doctoral Thesis, San Diego State University, San Diego, CA.

Lent, M. (2010). How Digital Technology has Changed Photojournalism. Retrieved from http://www.adorama.com/alc/0012375/article/How-Digital-Technology-HasChanged-Photojournalism 
Mehrabian, A. (1981). Silent messages: Implicit communication of emotions and attitudes (2d ed.). Belmont, Calif.: Wadsworth Pub.

Memmott, M. (2013). Chicago Sun-Times fires its photographers. The Two Way. Retrieved from http://www.npr.org/blogs/thetwo-way/2013/05/30/187292393/chicago-suntimes-fires-its-photographers

Mortensen, T., \& Keshelashvili, A. (2013). If everyone with a camera can do this, then what? Professional photojournalists' sense of professional threat in the face of citizen photojournalism. Visual Communication Quarterly, 20(3): 144-158.

Newton, J.H., (2009a). PHOTOJOURNALISM. Do people matter? Then photojournalism matters. Journalism Practice, 3(2): 233-243.

Russial, John.(2000). How Digital Imaging Changes Work of Photojournalists. Newspaper Research Journal, Vol. 21, No. 2

Taylor, J. (2000). Problems in Photojournalism: Realism, the Nature of News and the Humanitarian Narrative. Journalism Studies, 1 (1), 129-143.

Yaschur, C. (2012). Photojournalists Enjoy Web Work, Additional Autonomy. Newspaper Research Journal, 33(1), 71-85.

Zelizer, B. (1995). Words against images: positioning news work in the age of photography. In: Hardt H and Brennen B (eds) Newsworkers: Toward a History of Rank and File. Minneapolis, MN: University of Minnesota Press, pp. 135-159.

Zhang, Michael. (2010, August 5).The World's First Digital Camera by Kodak and Steve Sasson. Retrieved from http://petapixel.com/2010/08/05/the-worlds-first-digitalcamera-by-kodak-and-steve-sasson/ 